\title{
Dolly and Alice
}

\author{
Dan L. Burk* \\ University of California, Irvine, School of Law, 401 East Peltason Drive, Irvine, CA 92617, USA \\ *Corresponding author. E-mail: dburk@law.uci.edu
}

\begin{abstract}
ABST RACT
The opinion of the United States Court of Appeals for the Federal Circuit, In re Roslin Institute, rejecting patent claims to mammals cloned from somatic cells, was rendered about a month before the United States Supreme Court's decision in Alice Corp. v. CLS Bank International. The Alice opinion explicitly sets out the standard for determining whether an invention falls within statutory patentable subject matter. Thus one is thus left to wonder what the Roslin opinion might have looked like had it been decided only a few weeks later, after the Alice decision was published, with the benefit of the Supreme Court's further direction on patentable subject matter. In this essay I explore whether in hindsight the Alice standard might have dictated a different outcome in Roslin, suggesting how the two-part test articulated by the Supreme Court in Alice might apply to a 'products of nature' analysis for cloned mammals. Drawing on that analysis, I then use the Roslin case as a vehicle to highlight certain issues with the Supreme Court's current subject matter jurisprudence as applied to biotechnology. By juxtaposing Dolly with Alice, it becomes clear that the Supreme Court has revivified a number of dormant biotechnology patent problems in the guise of subject matter analysis.
\end{abstract}

KEYW O R D S: patents, cloning, intellectual property, subject matter, patent eligibility, biotechnology

\section{INTRODUCTION}

On May 8, 2014, the United States Court of Appeals for the Federal Circuit issued an opinion, In re Roslin Institute, rejecting patent claims to mammals cloned from somatic cells. ${ }^{1}$ The patent at issue covered animals such as the famous cloned sheep, Dolly, ${ }^{2}$

750 F.3d 1333 (Fed. Cir. 2014).

2 The name of the cloned sheep is said to have been drawn from a somewhat vulgar association between the type of cell used for cloning — a mammary gland cell — and the physical characteristics of the celebrated American

(C) The Author 2015. Published by Oxford University Press on behalf of Duke University School of Law, Harvard Law School, Oxford University Press, and Stanford Law School. This is an Open Access article distributed under the terms of the Creative Commons Attribution-NonCommercial-NoDerivs licence (http://creativecommons.org/licenses/by-nc-nd/4.0/), which permits non-commercial reproduction and distribution of the work, in any medium, provided the original work is not altered or transformed in any way, and that the work is properly cited. For commercial re-use, please contact journals.permissions@oup.com 
which had been produced without sexual reproduction from the cells of an existing adult sheep. ${ }^{3}$ Although Dolly was widely hailed as a scientific breakthrough in cellular and reproductive technology, ${ }^{4}$ the Federal Circuit panel held that such a cloned mammal was not sufficiently inventive to constitute patentable subject matter. ${ }^{5}$ Because of her genetic identity with a progenitor animal, Dolly was deemed a patent ineligible product of nature.

The Roslin opinion was rendered about a month before the United States Supreme Court's decision in Alice Corp. v. CLS Bank International, which explicitly sets out the standard for determining whether an invention falls within statutory patentable subject matter. ${ }^{6}$ Consequently, the Federal Circuit panel deciding Roslin attempted its subject matter analysis following the Supreme Court's prior opinion on DNA patentability in Myriad Genetics, without the benefit of the Supreme Court's later guidance in Alice. ${ }^{7}$ The standard applied to determine patentable subject matter in Alice is not found or discussed in the Myriad opinion, and although the Alice standard is derived from the earlier Supreme Court decision Mayo Collaborative Services v. Prometheus Laboratories, Inc., ${ }^{8}$ the proto-standard from Mayo is discussed in neither Myriad ${ }^{9}$ nor in Roslin.

Thus, one is thus left to wonder what the Roslin opinion might have looked like had it been decided only a few months later, after the Alice decision was published, with the benefit of the Supreme Court's further direction on patentable subject matter. It may be that the subject matter analysis made explicit in Alice would have changed the outcome, or at least the reasoning, of the Roslin decision..$^{10}$ In this essay, I explore whether in hindsight the Alice standard might have dictated a different outcome in Roslin, suggesting how the two-part test articulated by the Supreme Court in Alice might apply to a 'products of nature' analysis for cloned mammals. Drawing on that analysis, I then use the Roslin case as a vehicle to highlight certain serious issues with the Supreme Court's current subject matter jurisprudence as applied to biotechnology. I conclude that the Alice test demands a different view of Dolly's patent eligibility, but that significant issues remain to be resolved before the Alice test can be coherently applied to products of nature analysis.

\section{SITUATING ALICE}

Determining the application of Alice to the Roslin situation is not a simple exercise, as it requires making some sense of the relationship between the Myriad and Alice opinions.

country-western performer, Dolly Parton, See Dolly the Sheep Clone Dies Young, BBC News WorLd EdiTION, Feb. 14, 2003 http://news.bbc.co.uk/2/ hi/science/nature/2764039.stm (accessed Oct. 1, 2015).

3 Ian Wilmut et al., Viable Offspring Derived from Fetal and Adult Mammalian Cells, 385 NATURE 810 (1997).

4 See eg Elizabeth Pennisi, Breakthrough of the Year-Cloning: The Lamb That Roared, 278 SCIENCE 2038 (1997).

750 F.3d at 1336.

134 S. Ct. 2347 (2014).

See supra note 5 .

132 S. Ct. 1289 (2012).

See Dan L. Burk, The Curious Incident of the Supreme Court in Myriad Genetics, 90 Notre Dame L. REV. 505 (2014).

10 I note here that Dolly may well have been unpatentable due to other statutory impediments; the Patent Office rejected the Roslin claims not only for subject matter ineligibility, but also as anticipated and obvious over previous clones produced by other methods. See supra note 5. The Federal Circuit did not consider or affirm those grounds for rejection, Id., and here I consider only the Section 101 analysis. 
Roslin follows Myriad in implicating the 'product of nature' prohibition on patentable subject matter. ${ }^{11}$ Thus, understanding how Alice applies to Roslin requires understanding how Alice applies to Myriad. But since Myriad preceded Alice, and Alice nonetheless largely ignores it, we are left to speculate somewhat regarding Myriad's fit to the Alice test. I therefore begin by laying some groundwork regarding the reasoning in Myriad and its relationship to the Supreme Court's other subject matter cases. I then turn to Roslin, discussing how it might have been approached after Alice, in light of Myriad.

\section{Understanding Myriad Genetics}

All of the cases considered here struggle with long-standing uncertainties in the law of patentable subject matter. Section 101 of the American patent statute sets forth four categories of patent eligible subject matter: processes, machines, articles of manufacture, and compositions of matter. ${ }^{12}$ These categories have been read by the Supreme Court as broad, inclusive, and representative. ${ }^{13}$ The statute is silent as to what does not constitute patentable subject matter; ${ }^{14}$ presumably we can infer that inventions that lie outside the four broad and inclusive categories fail the requirements for subject matter. But, given that the explicit categories are highly inclusive, relatively little should fall outside their scope. Some excluded categories have over the years been supplied by the courts as a judicial gloss on the statute: abstract ideas, laws of nature, products of nature, and perhaps one or two related categories such as mental processes, are deemed to fall outside even the broadest reading of the statutory language. ${ }^{15}$

The Myriad Genetics opinion is included among the most recent suite of Supreme Court cases attempting to define the scope of the judicially created exclusions. ${ }^{16}$ In addition to being the most recent decision on subject matter prior to Roslin, the Myriad opinion is probably the closest to Roslin in subject matter; the Supreme Court's other opinions largely concern software or other processes. Myriad also is the only Supreme Court case to squarely address the 'products of nature' subject matter exclusion. ${ }^{17}$ So if the Roslin opinion seems a bit muddled (and we will see that it does), the Federal Circuit panel deciding the case perhaps cannot be entirely blamed for the outcome, as they were bound to follow the Supreme Court's recent subject matter guidance in Myriad, and that guidance is far from illuminating.

As I have shown at greater length in previous work, the reasoning in the Myriad case is largely incoherent. ${ }^{18}$ The opinion considers the patent eligibility of nucleotide sequences for certain cancer causing genes, designated BRCA1 and BRCA2. ${ }^{19}$ Myriad

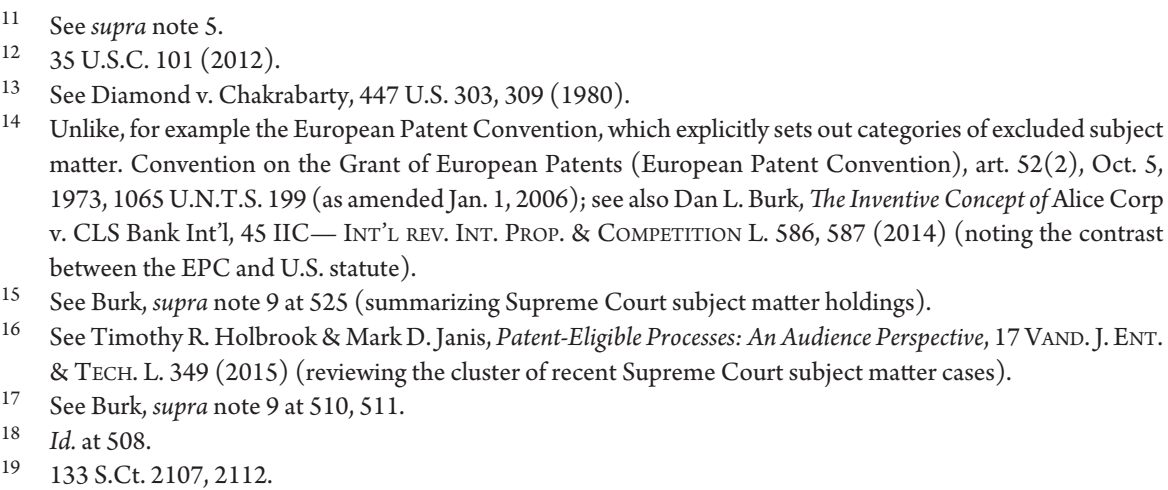


Genetics had claimed two kinds of nucleotides for the genes, genomic DNA sequences or gDNA, and complementary DNA sequences, or cDNA. ${ }^{20}$ The opinion holds that, as between these two particular types of DNA sequences encoding the genes, one type constitutes a patent ineligible product of nature, and the other does not. ${ }^{21}$ The sequence held not to be patent eligible was the (gDNA), which followed the native chromosomal sequence; the sequence held to be patent eligible was a complementary DNA sequence (cDNA), synthesized in the laboratory via a process termed reverse transcription. ${ }^{22}$ The gDNA sequence was held to constitute prohibited subject matter because it contained the same 'information' as sequences found in the wild; the Court dismissed as unimportant the molecule's structural differences from that found in the cell. ${ }^{23}$ But the Court held the cDNA sequence to constitute patent eligible subject matter $d u e$ to its structural differences from that found in the cell-despite the fact that it carried the same genetic information. ${ }^{24}$

It is thus difficult, and perhaps impossible, to divine from the Myriad opinion what exactly distinguishes a product of nature from patentable subject matter, at least so far as nucleotide sequences go - the holdings regarding the two types of nucleotides seem diametrically opposed regarding the importance of differences in structure or coding sequence. ${ }^{25}$ Given such unhelpful analytical distinctions, the Federal Circuit panel reviewing the Roslin patent had only the general outline of the Myriad result to work with in considering Dolly and other genetic clones. Without the specific framework articulated in Alice (and indeed even with it) Myriad may not have been the most trustworthy guide to determining the patent eligibility of the Roslin clones.

\section{Myriad and Alice}

Myriad's relationship to the Supreme Court's other subject matter cases is also a bit of a muddle. The Myriad opinion is sandwiched in time between the Supreme Court's previous opinion in Mayo v. Prometheus and the later Alice Corp. opinion. Alice skips backwards over Myriad to draw on Mayo for its analysis, attempting to distill the logic of Mayo into a workable standard. But Alice makes only a passing mention of Myriad, just as Myriad make little mention of Mayo. ${ }^{26}$ This could perhaps be attributed to the difference in the inventions at issue in the cases. Like the majority of the Court's subject matter decisions, whether contemporary or classical, both Alice and Mayo concern process claims, where the prohibited subject matter is either an abstract idea or a law of nature. The two categories are themselves sufficiently abstract that it is often hard to tell which is which, or which is being invoked in a given instance to exclude an invention from Section $101 .^{27}$

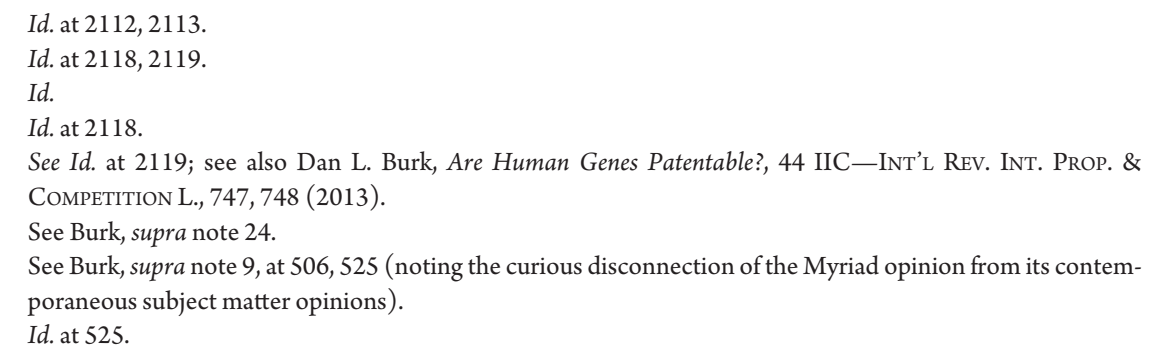


The Alice Corp. opinion offers an explicit framework for determining patentable subject matter. Alice sets forth a two-part test, ostensibly derived from Mayo v. Prometheus. ${ }^{28}$ According the Supreme Court, a subject matter analysis under Section 101 must first inquire as to whether the claimed invention entails one of the species of prohibited subject matter found in its prior opinions: an abstract idea, a law of nature, or (presumably) a product of nature. ${ }^{29}$ If the claimed invention involves a prohibited category, then under the second prong of the Alice test, analysis shifts to determining whether the patent is simply an attempt to claim the prohibited entity, or whether the inventor instead has added 'something more'. ${ }^{30}$ The something more must constitute an 'inventive concept' beyond an abstract idea, law of nature, or (presumably) a product of nature. ${ }^{31}$

I say 'presumably' in discussing products of nature in the Alice test, because unlike the other Supreme Court subject matter cases, Myriad concerns a product or material. ${ }^{32}$ Among the subject matter opinions, it is the Court's sole foray into products claims, in which products of nature rather than laws of nature are the prohibited category at issue. Indeed, prior to the Myriad decision, it would not have been irrational to question whether products of nature were in fact part of the Court's subject matter jurisprudence. ${ }^{33}$ Given the almost complete lack of reference between Myriad and the process subject matter cases, one might still plausibly wonder whether the Alice test is meant to apply to products of nature analyses. But the Alice opinion speaks broadly of the two-part analysis as the proper test for subject matter, intimating that it applies to all the judicially prohibited categories, including products of nature. ${ }^{34}$

Indeed, there is no suggestion in any of the subject matter cases that products are treated differently than processes in assessing patent eligibility. ${ }^{35}$ But since the test set forth in Mayo is not explicitly followed in Myriad, we are left to guess a bit as to how the nucleotide sequences in Myriad failed the test. If in fact Myriad follows the proto-Alice analysis of Mayo, and Myriad holds that cDNA is patent eligible but gDNA is not, then presumably cDNA passes the Alice test and gDNA fails it. The question then is how each of each kind of nucleotide polymer fits the two-part test, as the Myriad case itself is not explicit about following the Mayo/Alice test at all.

Considering the Myriad outcome as a result of the Mayo/Alice test, one has to conclude that $c D N A$ passes the first prong of the test and never reaches the second. It seems implausible that cDNA could pass the second prong of the test; there is no palpable inventive concept' in reverse transcribing the mRNA sequence derived from the BRCA1 or BRCA2 genes. The reverse transcription process that produces the CDNAs uses messenger RNA as a template to generate a cDNA transcript; creating cDNAs from this method is today the most routine and unimaginative of laboratory procedures. Neither

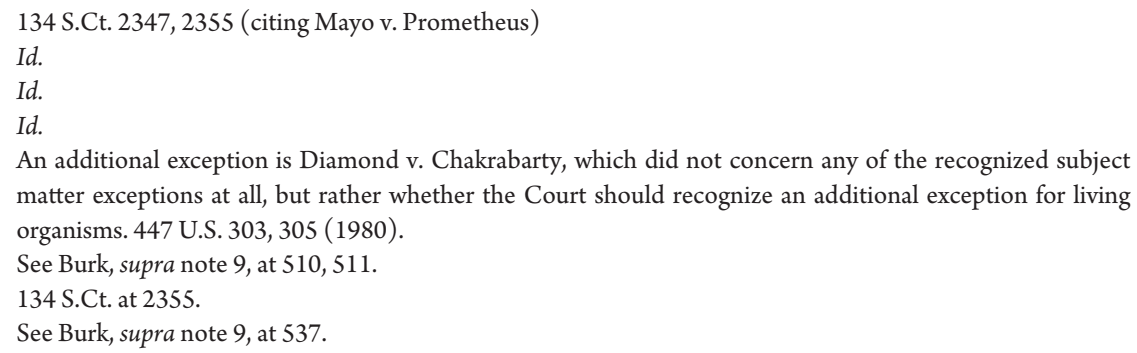


is there anything surprising about the structure of the Myriad cDNAs; they appear to follow the genomic nucleotide sequence minus non-coding 'introns' or intervening sequences that would be edited out of the mRNA transcript from which the cDNA was derived. This is exactly what one would expect given either the genomic sequence or the mRNA sequences.

One has to conclude, then, that within the Alice framework the Myriad cDNAs stand or fall on the first prong; that is, they must not entail a prohibited category, and so never reach the second prong of the test, and do not require an 'inventive concept' that they rather clearly lack. The Myriad cDNAs are apparently not products of nature (nor laws of nature and abstract ideas). Conversely, given their failure to meet subject matter eligibility, the Myriad gDNAs apparently fail both prongs: they must be products of nature, and must they lack an inventive concept as well. Informational identity with native DNA apparently classifies the gDNA as a product of nature, and one must conclude that the chemical and structural differences attending isolation of the molecule are insufficiently inventive to imbue the sequence with the 'something more' required under Mayo.

\section{MAKING SENSE OF ROSLIN}

Armed with what we can glean of the relationship between Alice and Myriad, particularly the application of Alice's subject matter test to products of nature, we are prepared to consider how the Roslin clone patent might have fared under the test. We must unfortunately begin by recognizing that, even allowing for the lack of the Supreme Court's subsequent guidance in Alice, the Roslin opinion is hardly a model of coherent judicial reasoning, either on its own terms or with regard to the Supreme Court's subject matter jurisprudence to that point.

For example, a substantial chunk of the opinion consists of a somewhat bizarre interlude discussing the Sears and Compco line of Supreme Court constitutional Supremacy Clause cases, which bar state law from prohibiting copying of subject matter that federal policy mandates remain in the public domain. ${ }^{36}$ The court suggests that the holdings in these cases somehow support the conclusion that cloning produces unpatentable copies. ${ }^{37}$ The discussion of these cases seems (to put it mildly) misplaced, first because Roslin involves no conflict between state and federal law, and second because the argument essentially assumes that clones are unpatentable as part of an argument leading to the conclusion that they are indeed unpatentable.

36 Sears Roebuck \& Co. v. Stiffel Co., 376 U.S. 225 (1964); Compco Corp. v. Day-Brite Lighting, Inc., 376 U.S. 234 (1964) (companion case to Sears); see also Dan L. Burk, Protection of Trade Secrets in Outer Space Activity: A Study in. Federal Preemption, 23 Seton Hall L. REV. 560, 608-12 (1993) (reviewing the Sears/Compco line of precedent).

37 See supra note 5, at 1337. This bizarre bit of reasoning also ignores various Supreme Court decisions subsequent to Sears, such as Kewanee Oil v. Bicron Corp., 416 U.S. 470 (1974), holding that the state trade secret law may protect subject matter excluded from patent eligibility, and JEM Ag Supply v. Pioneer Hi-Bred Int'l, 534 U.S. 124 (2001), holding that patentability does not preclude simultaneous intellectual property protection under the federal Plant Variety Protection Act. As I have observed elsewhere, patent eligibility and public domain status are not necessarily synonymous across various intellectual property schemes. See Burk, supra note 36 , at 623,624 . 


\section{Analogies and distinctions}

The remainder of the opinion relies on cases of greater relevance, although much of the reasoning remains problematic. The Federal Circuit panel looks to Myriad primarily for a dubious comparison between Dolly's nuclear genetic material and the ineligible genomic DNA sequences claimed in the earlier case. ${ }^{38}$ Dolly's primary claim to fame was that her cellular nuclei were derived from an existing adult sheep. ${ }^{39}$ Mammalian cells can be divided into somatic cells that are constituent of the body and have a full genetic complement, and gametes such as oocytes or spermatozoa that conjoin for reproduction and have only half the genetic complement of mature somatic cells. ${ }^{40}$ Dolly was created by a process of transferring the nuclear material of a somatic cell into an enucleated oocyte, which then developed into an embryo and gestated under the direction of the transferred genes. ${ }^{41}$

The identity between Dolly's nuclear material and that of her donor was the basis for the conclusion in Roslin that clones are patent ineligible products of nature. ${ }^{42}$ The Supreme Court characterized the DNA sequences in Myriad as having the same unaltered genetic information as found in human cells; so too the Federal Circuit characterized Dolly's cell nuclei as having the same unaltered genetic information found in her donor sheep's cells. ${ }^{43}$ Tellingly, although it compares Dolly to the gDNA molecules found patent ineligible in Myriad, the CAFC panel did not attempt to distinguish the clone from the cDNA molecules found patent eligible in that case.

To advance the comparison of Dolly to Myriad's gDNA sequences, the Federal Circuit adopted a line of argument from the Myriad opinion rejecting as inconsequential or irrelevant clear distinctions between the claimed invention and its natural analog, due to the absence of those distinctions as limitations in the patent claims. In Myriad, Justice Thomas' opinion rejects structural changes in the Myriad gDNA molecules as differentiating the claimed invention from materials found in nature, because he says the claims do not recite those differences as limitations. ${ }^{44}$ This reasoning is somewhat troubling because the Supreme Court has repeatedly declaimed that subject matter determinations should not be driven by 'the draftsman's art', ${ }^{45}$ yet reliance on such arguments makes the subject matter determination very much a product of the draftsman's art. The clear implication seems to be that a claim drafted to include such differences might qualify as patentable subject matter. ${ }^{46}$

The Roslin opinion travels the same road, rejecting the differences between cloned animals and those gestated by conventional means as distinctions between the claimed invention and products of nature because, the court says, those differences are not recited in the claims. ${ }^{47}$ Perhaps the most striking distinction raised by the patentees, and

38 See supra note 5, at 1337.

39 Robert G. McKinnell \& Marie A. Di Berardino, The Biology of Cloning: History and Rationale, 49 BIOSCIENCE 875 (1999); Anne McLaren, Cloning: Pathways to a Pluripotent Future, 288 SCIENCE 1775 (2000).

40 Eldra Solomon, Linda R. Berg \& Diana W. Martin., 222 Biology 253 (2014).

41 Heiner Niemann et al., Epigenetic Reprogramming in Embryonic and Foetal Development upon Somatic Cell Nuclear Transfer Cloning, 135 RePRODUCTION 151 (2008).

42 See supra note 5, at 1337.

43 Id.

44130 S.Ct. 2118.

45 Mayo, 132 S.Ct. 1289, 1294 (quoting Parker v. Flook, 437 U.S. 584, 593 (1978)).

46 See Burk, supra note 24, at 748.

$47 \quad 730$ F.3d at 1338. 
rejected by the panel, is the difference between nuclear and non-nuclear genetic sequences in each type of animal. The cloned animal claimed in the patent is created by transferring to a zygote a new nucleus, with its complement of genetic material, taken from the somatic cells of an existing animal. ${ }^{48}$ But not all DNA resides in the nucleus. Eukaryotic cell cytoplasm contains energy-producing organelles called mitochondria, and mitochondria carry their own DNA, separate from the nuclear DNA of the cell. ${ }^{49}$ Indeed, mitochondria reproduce themselves separately from the replication cycle followed by the rest of the cell. ${ }^{50}$

In conventional mammalian reproduction, cytoplasmic mitochondria come entirely from the mother, via her ovum; male gametes contribute no mitochondria to the zygote. $^{51}$ Thus, the genetic complement in cellular mitochondria descends through an entirely matriarchal line, accompanying a random selection of half the mother's nuclear genetic complement. ${ }^{52}$ Consequently, in conventionally gestated zygotes, a particular complement of mitochondrial DNA accompanies the nuclear complement of maternal DNA into the new organism. In the case of the Roslin clones, the mitochondria found in the cells of the clone would be derived from those in the cytoplasm of the recipient cell, with no relationship to the nuclear DNA. This seems a fairly clear distinction between the cellular composition of cloned animals and other conventionally reproduced animals.

The Federal Circuit rejected this distinction as absent from the claims. But the claims use the term 'cloned' which in reference to the process disclosed in the patent would necessarily entail this limitation. The specification of the Roslin patents in fact explicitly discusses the difference in mitochondrial genetic material. ${ }^{53}$ It is of course a general rule of claim interpretation that one is not to read limitations from the specification into the claims, ${ }^{54}$ but at the same time it is equally the rule that claims are to be read in light of the specification. ${ }^{55}$ I shall return later to the question of claims interpretation in relation to a subject matter analysis, ${ }^{56}$ but assuming the conventional rules apply, the difference between the DNA complement of a conventionally gestated animal and that of a cloned animal seems at least inherent in the term clone as that is explained in the Roslin specification. ${ }^{57}$

In a related passage, the opinion dismisses this same distinction on the grounds that the patentee had not explained what effect differences in mitochondrial DNA might have. This might be relevant for purpose of other sections of the patent act, for example if Dolly were purportedly non-obvious over prior art clones on the basis of the mitochondrial difference, or if there were some question as to whether the patent enabled

\footnotetext{
See Wilmut et al., supra note 3; Niemann et al., supra note 38.

James Watson et al., Molecular Biology Of The Gene 826 (4th ed. 1987).

This is taken as evidence that mitochondria likely descend from free-living organisms that at some remote epoch became symbiotes within eukaryotic cells. Id.

1 Id. at 1160.

52 See $I d$.

53 Patent Application 99/225,233 at 19. For that matter, the disclosure includes within the embodiments of the invention clones of transgenic animals, so that the term 'clone' need not mean genetically identical to a naturally occurring animal. Id. at 5 .

54 SciMed Life Sys, Inc. v. Advanced Cardiovascular Sys. Inc., 242 F.3d 1337, 1340 (Fed. Cir. 2001).

55 Vitronics Corp. v. Conceptronic, Inc., 90 F.3d 1576, 1582 (1996).

56 See infra note 92 and accompanying text.

57 See Dan L. Burk \& Mark A. Lemley, Inherency, 47 WM. \& MARY L. REV. 371 (2005).
} 
the claimed clones. But it is not at all clear that for purposes patent eligibility the patentee is required to justify a structural or physical distinctions from the native analog of the invention - the existence of such distinctions by themselves sets the invention apart from what is found in nature. Thus, for example, in Myriad, the patentee was not required to explain what effect or advantage came from the structural differences between the patent eligible cDNAs and native DNA; the presence of the difference was itself sufficient to satisfy the Section 101 inquiry. ${ }^{58}$

Nonetheless, ignoring such differences at the cellular and organism levels, the panel in Roslin asserts that Dolly is an identical genetic replica of a naturally occurring sheep. ${ }^{59}$ The paradox in that assertion is of course that a sheep with a genetic complement identical to that found in nature is not what one would find in nature. Nuclear genetic identity is of course a major difference, if not the major difference between the clone and anything found in nature; genetically identical mammals are not what one finds in the wild. This might not be true for certain simpler organisms that pass their exact genetic complement on to their progeny, or for plants, where genetic identity is a characteristic of some forms of vegetable propagation. But mammals such as sheep propagate via sexual recombination which typically renders them not genetically identical. $\mathrm{Nu}$ clear genetic identity can occur rarely in mammals due to gestational twinning, but as explained above twins are not clones ${ }^{60}$ — unlike any naturally occurring animal, Dolly might be said to have two genetic mothers: one who donated the cellular cytoplasm and another who donated a diploid nucleus. ${ }^{61}$

Much of the panel's reasoning in the case remains mired in this type of category error, assuming that because Dolly is - supposedly-identical to her donor sheep, the category of claimed mammalian clones is identical to the category of conventionally gestated sheep. But even if the former is assumed to be true, it does not make the latter true, as demonstrated by Dolly's genetic age. Mammalian chromosomes end with repetitive sequences called telomeres, which become degraded and shorter with each cycle of cell replication. ${ }^{62}$ Shortened telomeres are thus causally related to the cellular aging process. ${ }^{63}$ By virtue of inheriting a mature set of somatic cell chromosomes, rather than the freshly recombined set of germ-line chromosomes that would accompany natural conception, Dolly began life with shortened telomeres. Thus, Dolly was in a genetic sense 'born old' and lived a shortened life as a result. ${ }^{64}$

Specifically, the patent eligible cDNAs lacked the intervening sequences or 'introns' present in the native DNA sequence. See supra note 19 , at 2119 . The absence of these sequences is an artifact of the process by which cDNAs are produced: the mRNA from which cDNA is reverse transcribed lacks the introns. See WATSON et al., supra note 46 , at 749 . There is no hint in the Myriad patent that this confers any particular effect or advantage, nor does the Supreme Court suggest that it must.

See supra note 5, at 1338 .

Additionally, the Supreme Court in Myriad went out of its way to disclaim random fortuitous occurrences of the claimed invention in the wild as defining a product of nature. See supra note 19, at 2107, 2119.

The term 'diploid' refers to the full set of chromosomes present after gametes combine. See Solomon, supra note 39, at 218. Dolly might also be characterized as having two mothers and a father: a cytoplasmic donor, and the donors of the male and female gametes that originally combined to give rise to the adult nuclear donor cell.

Gerald Karp, Cell And Molecular Biology: Concepts And Experiments 494, 495 (2009).

Id. at 495 .

See Dolly the Sheep Clone Dies Young, supra note 2. 
This difference, too, was brushed aside by the Federal Circuit as a characteristic 'true of any copy' ${ }^{65}$ But it is no argument to simply label Dolly a copy. A photograph of a tree, a sculpture of a tree, and a model of a tree are all 'copies' of an item found in nature, but nonetheless are not naturally occurring artifacts, being clearly the handiwork of a human creator. They each resemble a natural object but differ from it in significant respects. Similarly, Dolly or other clones may resemble an existing animal, but are not naturally occurring organisms, instead bearing the mark of human handiwork. Specifically, naturally conceived zygotes do not have Dolly's unnaturally shortened telomeres, nor do new-born lambs, and nor even adult sheep of Dolly's chronological age when she died. The question is not whether Dolly was a copy, but whether such a copy existed in nature.

\section{Products of nature}

In addition to the rather strained analogies to Myriad, the Roslin opinion offers some strained analogies to other Supreme Court opinions dealing with patents on biological inventions. The Federal Circuit panel compares the claimed clones to the inventions considered by the Supreme Court in Funk Brothers v. Kalo Inoculant ${ }^{66}$ and in Diamond v. Chakrabarty. ${ }^{67}$ The former decision concerned a mixture of agriculturally beneficial bacteria, which was held unpatentable under the pre-1952 patent statute. ${ }^{68}$ The Chakrabarty case concerned a modified microorganism, capable of digesting petroleum, which was held patentable under the current statute. ${ }^{69}$ Although often cited with regard to patentable subject matter, neither of these decisions is an especially good guide to determining the relevant exceptions to patent eligibility under Section 101. As I have pointed out elsewhere, Funk Bros. was decided prior to the enactment of the current statute, under a different standard, ${ }^{70}$ and Chakrabarty held that living organisms are patentable subject matter, not that the claimed invention was (or was not) a product of nature. ${ }^{71}$

Indeed, it is worth noting that much of what passes for analysis in the Roslin opinion dwells on the Supreme Court's dicta from Chakrabarty that the organism under consideration there was 'markedly different' from those found in the wild. ${ }^{72}$ This comment in Chakrabarty was part of the Court's discussion as to whether living organisms could be patentable subject matter, ${ }^{73}$ but even were it a holding as to what constitutes a product of nature, the opinion offers little guidance as to what 'markedly

\footnotetext{
See supra note 5, at 1338 (quoting USPTO Board of Patent Appeals and Interferences).

73447 U.S. at 306 ('Congress thus recognized that the relevant distinction was not between living and inanimate things, but between products of nature, whether living or not, and human-made inventions').
} 
different' might mean. The marked difference endorsed in Chakrabarty is in fact rather poorly demarcated. The Federal Circuit appears to have forgotten-as perhaps has the Supreme Court-that Ananda Chakrabarty's petroleum-digesting Pseudomonas species bacterium was created by moving existing genetic sequences from different strains of bacteria into a single strain by means of the bacteria's 'natural' genetic exchange mechanism of conjugation. ${ }^{74}$ To be certain, Chakrabarty carefully selected the bacterial strains he wanted to cross, and stabilized the exchanged genetic components after conjugation. But it is not altogether clear how the result is 'inventively' distinguishable from that in Roslin: bacteria normally exchange genes by means of conjugation in the wild without human intervention, but sheep ova never 'naturally' lose their nuclei and acquire the nucleus of a different animal's somatic cell without determined human manipulation.

\section{APPLYING THE ALICE TEST}

And this brings us at last to Alice. Rather than a 'markedly different' standard, Alice frames the subject matter inquiry as the two-step test described above. Applying the first step, asking whether the patent encompasses a prohibited subject matter category, either seems to disfavor a finding of a prohibited category or are at worst indeterminate. The Roslin patent encompasses product claims, so the relevant prohibited category would be products of nature. Given the characteristics I have reviewed thus far, it is questionable that the Roslin clones would constitute products of nature, any more than the Myriad cDNA molecules did. Like cDNA, the Roslin clones are the product of synthetic laboratory processes, and entail differences from their natural counterparts at least as distinctive as the missing intervening sequences in the Myriad cDNAs. The fact that one portion of the clones - their nuclear material - was identical to that of a natural counterpart seems no more subject matter disqualifying than the fact that the coding sequences of the Myriad cDNAs were identical to the coding sequences of naturally occurring BRCA1 and BRCA2 gDNA, or for that matter that the nuclear material of Chakrabarty's bacterium was identical to the nuclear material of Pseudomonas species found in the wild.

\section{Taking the second step seriously}

One might nonetheless expect that, had the Federal Circuit panel in Roslin applied the Alice test to the clones, the claims would have failed the first prong. The panel seemed determined to analogize the clones to the Myriad gDNAs rather than the Myriad cDNAs, and given that the Myriad opinion offers little in the way of principled distinction between its gDNA and cDNA holdings, the Federal Circuit panel may have felt compelled to force the Roslin clones into the first prong's products of nature box. In some senses, the Roslin panel's analysis might be viewed as encompassing only the first prong of the Alice test; the analysis looks for a product of nature and then stops. To the extent that Roslin follows Myriad, this might be expected; as I have indicated above, the Myriad outcome seems to rest entirely on the first step of the Alice test. ${ }^{75}$

74 See U.S. Patent 4,259,444 (1981); see also Ronald D. Porter, Conjugation in Modern Microbial Genetics 463 (Uldis N. Streips \& Ronald E. Yasbin eds., 2d ed 2002) (describing the process of bacterial conjugation).

75 See supra note 35 and the accompanying text. 
But, even assuming that the cloned sheep failed the first prong of the Alice test, the analysis would then move to the second prong to look for an 'inventive concept' that takes the claimed invention beyond an attempt to merely capture the prohibited category of subject matter identified in the first step. ${ }^{76}$ Following the claiming logic of Myriad, as the Federal Circuit did, such an inventive concept would need to be found in the claims. The Roslin patent claims surely entail such an inventive concept in the method of creating the sheep. The claims recite 'clones', which the specification discloses were produced by a novel method that is universally acknowledged to have been a highly significant and difficult advance in reproductive technology-an 'inventive concept' if there ever was one. ${ }^{77}$ Both Alice and Mayo hold that implementing prohibited subject matter by means of conventional, routine, or off-the-shelf technology fails the inventive concept requirement of step two. But the creation of the Roslin clones was not achieved via conventional, routine, or readily available techniques; rather, biologically 'reprogramming' somatic cell DNA to generate a clone constituted a novel technical breakthrough. ${ }^{78}$

To the extent that the Roslin opinion attempts to follow the 'markedly different' dictum from Chakrabarty, the Alice decision perhaps puts some flesh on the bones of that standard: where the invention incorporates the disfavored category, product of nature, the marked difference necessary to place a claimed invention within patentable subject matter is an 'inventive concept' that separates the claims from what might be found in the wild. One might of course complain that at some level an 'inventive concept' is no more concrete than a 'marked difference'. But the former criteria at least indicates the type and nature of the difference, suggests what differences might be relevant, and points toward a substantive distinction between products of nature and products of human ingenuity.

The search for an inventive concept cannot be quite the same exercise for product claims as it is for process claims. Initial step determination as to whether an invention falls into one of the forbidden categories of excluded subject matter has something to do with the breadth of the attendant claims, but also much to do with the degree of generality with which it is regarded by a reviewing judge or examiner. Much as in copyright law's famous 'level of abstractions' test, ${ }^{79}$ the first prong of the Alice test asks the reviewer of a patent to assign the invention to some level of an increasingly abstract scale of interpretations. Thus, in Mayo, the Supreme Court views the claimed invention as highly abstract, effectively as a claim to a naturally occurring correlation between illness and symptoms. It is therefore not surprising that one can hardly tell if the Mayo patent fails for claiming a law of nature or an abstract idea, since viewing the patent as a claim to a law of nature requires viewing it as an abstraction. Similarly, in Alice, the Court views the financial transaction process at issue as entirely conceptual, abstracting away the disclosure (and claims) that discuss the apparatus and media implementing

76 See Alice, 134 S.Ct. at 2355.

77 Cf. infra notes 83, 92 and the accompanying text (discussing product by process formulations of the Roslin claims).

78 See supra notes 2, 3 and the accompanying text.

79 See Nichols v. Universal Pictures Corp., 45 F.2d 119 (2d Cir. 1930) (first articulating the levels of abstraction test for copyright similarity); Dan L. Burk \& Mark A. Lemley, Quantum Patent Mechanics 9 LEWIS \& CLARK L. REv. 29, 34-40 (2005) (analogizing copyright levels of abstraction to patent claim interpretation). See also Tun-Jen Chiang, The Levels of Abstraction Problem in Patent Law, 105 NW. U.L. REV. 1097 (2011) (same). 
the method-small wonder the opinion concludes that the method is an ineligible abstract idea; the Court chose to view it at a high level of abstraction.

The method claims in such cases lend themselves to such abstraction, because processes are by their nature relational — even when the claims recite devices or apparatus, the invention lies in the relationships between such objects, and not in the objects themselves. But it is far more difficult to adopt an abstract level of interpretation for composition claims, because some concrete structure or formulation will typically be used to define the invention. Hence, the products of nature category, rather than the abstract idea, will typically be the relevant category against which to measure compositions of matter-one might try to view Chakrabarty's bacterium as the 'idea of a microorganism that digests petroleum', but properly enabled claims are more likely to require consideration of the invention as a particular strain of bacterium imbued with particular genetic elements.

The analytical move toward abstraction may be one reason that Justice Thomas in Myriad emphasizes the 'informational' similarities between the isolated gDNA molecule and chromosomal nucleotide sequences, and refuses to view the invention at the more concrete structural level adopted in the Federal Circuit holding below. Focusing on the sequence rather than the structure allows Thomas to treat the genomic DNA sequence as the 'idea' of a molecule. In contrast, the cDNA is not regarded at the abstract 'informational' level, but at the level of its particular instantiation, as a structure lacking intervening sequences. While it is not entirely clear what principled distinction causes the Court to adopt these different levels for analysis, the outcome once they adopted is fairly clear: by ignoring structural features, compositions of matter can be treated the abstract way that processes are treated in Mayo.

It is this abstractive sleight of hand that the Federal Circuit mimics, somewhat ineptly, for its analysis in Roslin. The Federal Circuit opinion essentially abstracts away the concrete instantiation of the Roslin invention-ignoring the invention's relative chronological and genetic age, non-nuclear genetic elements, and the non-natural identity between donor and offspring sheep. But there is in Dolly no ineffable 'informational' character for the Roslin panel to rely upon for a high level of abstraction as Thomas does in Myriad. Instead the panel relies only on blunt and implausible dismissals of physiology to pare away Dolly's non-native differences. The criteria for deciding that differences such as DNA introns do matter, but that those such as non-identical mitochondrial DNA do not, remain as elusive as the degree of abstraction to be chosen when considering a diagnostic test.

The Alice opinion holds out the hope that abstract or naturally occurring process claims might, at least in theory, be saved on the second prong of the test by 'something more' that transforms the claims into patent eligibility by means of an inventive concept. But this second prong recovery seems an unlikely and perhaps impossible occurrence for composition claims: if the invention is insufficiently distinguishable from its native counterpart that it fails the first prong of the test, what might be left to render it inventive on the second? Presumably any unique structural features have already been taken into account in the initial inquiry and found wanting. If the Alice test is not to collapse into a single question, the inventive concept for compositions of matter must lie elsewhere. If the inventive concept is not found in the product's structure, then it must lie in its function, with the processes surrounding its making or use. 


\section{The preemption criterion}

Our understanding of the 'inventive concept' necessary to take claims outside the prohibited product of nature category might additionally be clarified by reference to the guiding principles articulated by the Supreme Court in all of its recent subject matter decisions. Stepping away for a moment from the formalisms of the Alice framework, one might ask how well the Federal Circuit's analysis fits with the purpose of the judicially created subject matter exceptions. The Court has been clear that the purpose of its judicially created subject matter restrictions is to prevent fundamental concepts and materials, on which all inventors must draw, from being caught up in patent claims. ${ }^{80}$ Avoiding such 'preemption' of future inventive activity is the guiding purpose by which subject matter restrictions are judged. ${ }^{81}$

There is little evidence that the Roslin patent attempts to capture fundamental or basic science on which future invention will depend, or if it does so, there is no indication in the Roslin opinion that this informed the analysis of patentable subject matter. The Federal Circuit opinion spends no time in discussing the potential for preemption of downstream invention by the patent claims. This is perhaps unsurprising, given that the Federal Circuit has shown extreme reluctance to inquire into preemption in its post-Myriad jurisprudence. Preemption is brushed aside on the rationale that 'Where a patent's claims are deemed only to disclose patent ineligible subject matter under the Mayo framework, as they are in this case, preemption concerns are fully addressed and made moot ${ }^{82}$ This may be true, but conceives the issue entirely backwards. Given that pre-emption of downstream innovations is one of the few markers the Supreme Court has offered regarding the substance of prohibited subject matter categories, preemption seems antecedent to 'deeming' claims to disclose such subject matter. The subject matter exclusion may be categorical, but preemption defines the category. The issue is not that a subject matter exclusion needs to be recognized in order to avoid preemption; it is that preemption needs to be recognized in order to know when to impose a subject matter exclusion.

Preemption implicates practical as well as conceptual subject matter criteria. I have suggested previously that the Court's subject matter jurisprudence is largely an attempt to drive patent holder toward narrower claiming, as a proxy for excluding fundamental 'building block' developments from patentability. ${ }^{83}$ Probably there is some correlation between breadth of claiming and fundamentality of inventions, despite the Court's warning against determining patent eligibility according to the 'draftsman's art'. And here again, taking seriously the stated purposes of the Mayo/Alice test points toward patent eligibility. Plainly the Roslin patent is not attempting to claim all sheep, nor even all genetically identical sheep. The claims only extend to sheep produced by the cloning process, a limitation that constrains the patent to the specific and novel implementation disclosed by the applicant.

\footnotetext{
Alice, 134 S. Ct. at 2354; Gottschalk v. Benson, 409 U.S. 63, 67 (1972).

Bilski v. Kappos, 561 U.S. 593, 611-12 (2010); Mayo, 132 S.Ct. 1289, 1293.

See eg Ariosa Diagnostics, Inc., v. Sequenom _- F.3d _- (Fed. Cir. 2015).

See Burk, supra note 9 , at 535.
} 


\section{IMPLICATIONS FOR THE ALICE TEST}

The Alice test casts Dolly the sheep in a different light, suggesting the potential for a different outcome in Roslin. But at the same time, the Roslin opinion highlights certain problematic features of Alice as applied to biotechnology. In particular, Roslin raises questions from the early days of biotechnology patenting that were thought laid to rest: the question of product-by-process claims, and the relationship between patent and process, known to patent lawyers as the 'Durden problem'. In their original incarnations, these issues were long ago resolved, or at least relegated to a position of doctrinal détente; but as the Roslin opinion shows, they now threaten to reappear in the context of the Alice subject matter test.

\section{Product-by-process claims}

The implication of the cloning process in the Roslin claims raises the question as to whether this type of product patent might be treated under a specialized form of claiming, known as 'product by process' claiming, and whether that characterization would make a difference to the outcome. The patentee specifically disclaimed this approach in its arguments to the Patent Office, so that the question remains unaddressed on appeal. ${ }^{84}$ Nonetheless, the Roslin claims implicitly entail the cloning process, and could well have been drafted to explicitly recite the process and that path may seem inviting to future applicants seeking patents on similar biological inventions.

Claims of this type were originally formulated as a claiming strategy for products that were difficult to describe; rather than attempt to capture in language the elusive limitations of a problematic product, the invention could be claimed as the product of its more easily described process. ${ }^{85}$ It was generally understood that, since the product was the subject of a patent application, it was the product that would be examined for novelty and non-obviousness against identical or similar prior art products, no matter what process produced such products. ${ }^{86}$ This followed from the long-standing rule that preparation of a known product by a new process does not confer patentable novelty on the product, ${ }^{87}$ and posed a significant impediment to early biotechnology patents, which frequently generated known materials from novel processes. ${ }^{88}$ The Patent Office continues to follow this rule in examination of claims having the product by process format. $^{89}$

The same rule was thought to apply in an infringement setting. ${ }^{90}$ But Federal Circuit decisions became fragmented on the proper scope of such claims when judging infringement: having been described as the product of a certain process was the claim limited to the product only when produced by that process? Or was the product

84 Ex Parte Roslin Inst., 2010-006828 at 13 (PTAB Feb. 7, 2013). However, the Board effectively treated the claims as product by process for purposes of anticipation and obviousness. Id. at 21. My question here is what a product-by-process structure means for the Alice subject matter analysis, not for anticipation or obviousness.

85 COMPuter \&TeCH. L. J. 1, 33-34 (1991).

86 In re Thorpe, 777 F.2d 695, 698, 227 USPQ964, 966 (Fed. Cir. 1985).

87 See Amgen v. F. Hoffman La Roche, 580 F.3d 1340, 1369-70 (Fed. Cir. 2009).

88 See Burk, supra note 84; David Beier \& Robert H. Benson, Biotechnology Patent Protection Act, 68 DENV. U. L. Rev. 173, 184-85 (1991).

89 United States Patent and Trademark Office, Manual of Patent Examining Procedure $\S 2113$ (9th ed. 2014).

90 See Burk, supra note 84 . 
covered by the patent when produced by any process, as it would have been if claimed in terms of its own characteristics $?^{91}$ Current Federal Circuit jurisprudence has adopted the latter position, treating the process recited in the claims as a limitation on the claims, rather than as a descriptive mechanism. ${ }^{92}$

A Section 101 subject matter inquiry is not a Section 102 novelty analysis, nor a section 271 infringement analysis. But the history of product-by-process claims under these provisions leaves the question as to how a product by process claim would be treated under Section 101: Would the process recited be treated as a limitation, and would such a limitation matter? To the extent that current subject matter jurisprudence seems to recapitulate a novelty inquiry, the answer might well be that a process limitation would be immaterial: a product that exists in nature remains ineligible for a patent, no matter how produced. If one ignores the genetic, cytological, and physiological differences between Dolly and her predecessor sheep-as the Federal Circuit did-to conclude that she was 'identical' to existing sheep, then her origins might not matter.

On the other hand, given the Federal Circuit panel's repeated references to the claim limitation in determining subject matter eligibility, and its apparent invitation to draft clone claims in terms of their originating process, it might be that a process limitation would have been treated under 101 as it might under an infringement analysis, limiting the subject matter to non-naturally occurring products. This might matter from an Alice/Mayo preemption standpoint; the process limitation would then demarcate claims to Dolly from claims to conventional sheep that must remain accessible to the public and to future inventors. This would also appear consonant with the treatment of the DNA sequences in Myriad; the major distinction between the cDNA and gDNA claims appears to be the method of producing the former. If one takes seriously Justice Thomas' assertion in Myriad that informational identity is what matters as between a gDNA molecule and its native analog, then cDNA and gDNA are informationally the same, but produced by different processes; that is, the cDNA was synthesized via an 'unnatural' laboratory process.

All of these considerations are overshadowed by an additional troubling problem in the Alice framework that some other commentators have already noticed. ${ }^{93}$ The Supreme Court rejected arguments regarding the structure of gDNA because these characteristics were not incorporated into the Myriad claims; the Federal Circuit rejected arguments regarding Dolly's non-nuclear genetic complement because that was not incorporated into the Roslin claims. The Federal Circuit treated the Roslin claims as product rather than product-by-process claims because the patentee declined to make a product-by-process argument. The Alice opinion directs lower courts to look for an 'inventive concept' that adds something more than a bare claim to prohibited subject matter. All of this subject matter analysis with reference to the patent claims requires courts to construe the claims, but apparently without formal claim construction,

91 Compare Scripps Clinic Research Foundation v. Genentech, Inc., 927 F.2d 1565, 1583 (Fed. Cir. 1991) (holding that product by process claims cover the claimed product without regard to the process of preparation) with Atlantic Thermoplastics Co. v. Faytex Corp., 970 F.2d 834, 847 (Fed. Cir. 1992) (holding that the process recited in product by process claims is a limitation for purposes of infringement).

92 Abbott Labs v. Sandoz, Inc. 566 F.3d 1282, 1293 (Fed. Cir. 2009); Amgen v. F. Hoffman La Roche, 580 F.3d at 1370 .

93 See Holbrook \& Janis, supra note 16 at 363, 364. 
which normally takes place at a particular time and in a particular context for patent adjudication.

\section{Durden redux}

The treatment of product-by-process claims within the Alice test leads to another, perhaps even more striking question, which is thrown into sharp relief by the Roslin facts. This stems from the ambiguous doctrinal content of the patent eligibility inquiry. I have argued in previous work that the question of patentable subject matter has no independent analytical content, but is rather forced to borrow from other sections of the patent statute for its substance. ${ }^{94}$ Thus, the analysis of subject matter at different times takes on the aspects of a sort of pseudo-novelty, pseudo-obviousness, or even pseudo-utility assessment, asking whether the claimed invention is something different than what is found in nature, whether it has uses or applications that distinguish it from its natural counterparts, or whether it is only a trivial advance over what can be found in the wild. ${ }^{95}$ Indeed, one might characterize the analysis in Roslin as a type of pseudo-novelty analysis, asking in effect whether every element of the claimed invention is found in naturally occurring animals. ${ }^{96}$

This means that the relationship between Section 101 and other limiting statutory sections is at best unclear. As presently employed, Section 101 seems to duplicate doctrinal filters associated with other patentability provisions, leaving one to wonder what purpose is served by such redundancy. In particular, I have previously argued that and that the 'inventive concept' language of the Alice test is an attempt to screen out undesirable subject matter by importing into Section 101 a kind of obviousness analysis that since the 1952 incorporation of obviousness into the patent statute had been reserved for assessment under Section 103. ${ }^{97}$ Since the articulation of the Alice test, patent eligibility doctrine appears to constitute a kind of pseudo-obviousness inquiry.

Thus, the introduction of the Alice 'inventive concept' requirement into Section 101 might leave some question as to what work Section 103 is now doing, or whether an invention that is found 'inventive' under Section 101 would ever fail obviousness under Section 103. The standards for the two are of course not necessarily identical; Section 103 specifies that obviousness is to be assessed at a particular time (the time an application is filed) against particular prior art (the categories contemplated in Section 102) according to a particular standard (the knowledge and skill of the person having ordinary skill). ${ }^{98}$ Section 101 sets forth no such criteria for 'inventive concepts' since this requirement is entirely a judicial creation, rather than the product of statutory language. Following an aberrant and discredited bit of analysis in the 1979 Parker v. Flook

94 Burk, supra note 70.

95 For example, each of these approaches is found in the Federal Circuit opinions accompanying the Myriad case. See Id.

96 Cf. Structural Rubber Prod. Co. v. Park Rubber Co., 749 F.2d 707, 715 (Fed. Cir. 1984) (every element of the claimed invention must be found in a prior art reference for the invention to be anticipated under the Section 102 novelty provisions).

97 See Burk, supra note 14.

9835 U.S.C. 103. 
decision, ${ }^{99}$ the Supreme Court in Mayo has hinted that nature itself is the standard against which inventiveness is assessed, ${ }^{100}$ meaning that the outcome of a 101 inventive concept' assessment might be quite different than a 103 obviousness assessment.

At the same time, the two standards are at least conceptually similar; both are directed to the determination of 'inventiveness' in one form or another. The result of such similarity is that importing obviousness concepts into Section 101 brings with it baggage formerly associated with Section 103. If Section 101 can be distinguished from Section 103 because it lacks the criteria that define obviousness under Section 103, so too it lacks the accumulated precedent that has settled many of the problems that have historically cropped up in the analysis of obviousness, leaving it vulnerable to controversies that have haunted Section 103. Although a careful consideration of the Myriad decision hinted at the potential for populating Section 101 with such doctrinal revenants ${ }^{101}$, the Roslin case squarely raises at least one of them, arising from the relationship between the patent eligibility of product and process.

Section 101 recites three categories of patentable subject matter that constitute product patents: machines, compositions, and manufactures. ${ }^{102}$ It also recites a fourth, rather different category of subject matter: processes. ${ }^{103}$ These two general categories are intimately related; products are the results of processes, the inputs into processes, and the substrates of processes. ${ }^{104}$ Given these causal relationships, there have been numerous past questions regarding the ontological status of processes and products when one or the other was judged patentably novel and non-obvious: Does a novel or nonobvious substrate necessarily give rise to a novel or non-obvious process? Does a novel or non-obvious end product necessarily arise out of a novel or non-obvious process? ${ }^{105}$

Logically, one can argue that a novel substrate, to a process, must by definition give rise to a novel process - if the substrate is previously unknown, the process in which it is involved cannot have previously been known. As one opinion reasoned, without possession of the novel starting material it cannot be obvious to use the starting material in the process, for 'one cannot choose from the unknown'. ${ }^{106}$ Similarly, if a product would not have been obvious to one of ordinary skill, then logically the process that produced it cannot have been obvious to one of ordinary skill; if the output is non-obvious, then it cannot have been produced by obvious means. Courts struggled over decades to determine whether such logical strictures could lead to predictable patent doctrine

99 See Parker v. Flook, 437 U.S. 584, 592 (1978)( 'Whether the algorithm was in fact known or unknown at the time of the claimed invention. .. it is treated as though it were a familiar part of the prior art.'). This dictum was with good reason subsequently rejected by the Court in Diamond v. Diehr, 450 U.S. 175, 189 n. 12. (1981).

100 132 S.Ct. at 1304.

101 See eg Dan L. Burk, Anticipating Patentable Subject Matter, 65 STAN. L. Rev. OnLINE 109 (2013) (discussing the importation of Section 102 and 103 inherency problems into Section 101); cf. Dan L. Burk \& Mark A. Lemley, Inherency, 47 WM. \& MARY L. REv. 371, 405-8 (2005) (predicting the potential for the inherency doctrine in patentable subject matter).

10235 U.S.C. 101

103 Id.

104 See Burk, supra note 9 at 527; Dan L. Burk, Method and Madness in Copyright, 2007 UtAH L. Rev. 587, 608-9.

105 See Dan L. Burk, The Problem of Process in Biotechnology, 43 Hous. L. REv. 561, 573 (2006); Burk, supra note 84 at 42,43 .

106 In re Mancy, 499 F.2d 1289, 1293 (C.C.P.A. 1974). 
when novel materials were incorporated into known processes, or when known processes were used to produce novel materials. ${ }^{107}$

The decisions attempting to rectify the product and process relationship came to be known as the Durden line of cases, from the key decision rendered with regard to a chemical process. ${ }^{108}$ In general, the Durden cases appeared to hold that where a starting material was known in the art but the end product was non-obvious, employing a known process to generate the product should be deemed obvious and unpatentable; whereas if the end product was known and obvious, but the starting material was patentably novel and non-obvious, then the process should be deemed patentable as well. ${ }^{109}$ The former type of cases often were often grouped together as involving a 'method of making' a patentable compound, whereas the latter type of cases became grouped together as involving a 'method of using' a patentable compound, and attempts were made to distinguish the outcomes of the two sets of cases on that basis. ${ }^{110}$

These opinions suggested that patentable end products might be made from old and obvious processes, but patentable starting materials imbued old processes with their non-obvious qualities. ${ }^{111}$ The cases repeatedly focus on the question of whether in an obviousness analysis a court or the Patent Office was effectively treating a novel product as if it were prior art in determining the obviousness of its production. Indeed, the treatment of such biotechnology applications by the Patent Office, under what seemed to be a per se hindsight rule, resulted in a successful lobbying effort to amend Section 103 to add a specialized provision for biotechnology, allowing applicants to elect prosecution of product and process claims in the same application, and statutorily requiring under such circumstances that the patentability of the one be imputed to the other. ${ }^{112}$

At the same time, the Federal Circuit became increasingly insistent that bright-line rules were unworkable in such obviousness determinations. One could not assume the existence of a novel product in order to ask whether one of ordinary skill might be motivated to prepare it via an existing process, or alternatively would be motivated to use it in an existing process to produce some end product. ${ }^{113}$ Ultimately, this became the judicial resolution for the recurring problem; rejecting bright-line rules regarding 'methods of making' and 'methods of using', the Federal Circuit held that, as provided by the language of Section 103, obviousness must of products or processes must be determined on a case-by-case basis against the relevant prior art, notwithstanding their relationship to related inventions. ${ }^{114}$

While that approach provides an answer for sorting out the obviousness standard in Section 103, the Supreme Court has now created an analogous problem within Section 101. Importing pseudo-obviousness into Section 101 resurrects the Durden question, but in the context of patentable subject matter. The Roslin case starkly demonstrates the problem. The patents at issue in Roslin concerned particular products, that is, Dolly or other clones. The process of producing such clones was not at issue in the case, but there

107 See Burk, supra note 84 at 43, 57 (detailing the history of such cases).

108 In re Durden, 763 F.2d 1406 (Fed. Cir. 1985).

109 See Burk, supra note 100.

110 Id.; Burk, supra note 84 at 43.

111 Burk, supra note 100 at 574.

11235 U.S.C. 103(b). This provision was removed under the 2012 statutory revision in the America Invents Act.

113 Id.

114 In re Brouwer, 77 F.3d 422 (Fed. Cir. 1996). 
seems little dispute that the cloning process would constitute patentable subject matter, and indeed the Federal Circuit suggests in passing that any innovation attributable to Dolly's inventors should and would be better protected by process claims.

The Durden cases plumb the relationship between product and process, exploring the impact of substrate novelty or non-obviousness on those qualities in attendant processes. The Alice test contemplates 'inventive concepts', not quite the same issue as novelty or non-obviousness, but clearly related. As in the Durden cases, inventiveness of process may be reflected in its products, and vice versa. As I suggested above, under some conceptions of 'inventive', an inventive process such as that in Roslin-something that is a decidedly 'unnatural' manipulation of physical materials - must logically give rise to an 'inventive' product, particularly if it is defined through a product by process claim. Conversely, in parallel to the Durden obviousness cases, one would expect that there will be subject matter cases in which the inventive nature of products or substrates implies inventiveness of attendant processes.

There is no reason to believe that this issue is unique to Roslin; rather, as in the Section 103 Durden cases, the question will arise wherever there are companion products and processes, one or the other of which qualifies as patent eligibly inventive under the Alice test. For reasons that I have articulated in previous work, biotechnology is an inherently fertile field for the confluence of product and process inventions; ${ }^{115}$ so as a practical matter, this means that the issue will routinely come up in biotechnology and related wet sciences. One is tempted to say that the new Section 101 analog of the Durden problem should be solved the way that the old Section 103 version of the problem was solved. If one imports Section 103 problems into Section 101, perhaps one can import the Section 103 solutions as well. But one cannot escape the quandary by saying, as the Federal Circuit did in the context of Section 103, that one must simply decide on a case-by-case basis, by following the statutory criteria. In Section 101, there are no statutory criteria to save us.

\section{CONCLUSION}

Dolly may well have been unpatentable on grounds of anticipation or obviousness. ${ }^{116}$ But as a question of subject matter eligibility, the Federal Circuit's treatment of patents covering Dolly the sheep might have benefitted from the framework outlined in the later Alice opinion, and considering how Alice might have changed the Roslin analysis offers a worthwhile exercise in determining how the Alice framework operates in the context of products of nature. At the same time, reconsideration of Dolly's situation simultaneously reveals how, as applied to biotechnology, the Alice approach creates confusion across a range of doctrines, including both product-by-process claims and a Section 101 analog of the old Durden analysis. And, although the question extends well beyond my brief in this particular essay, it is worth at least noting that, given the technological subject matter of the Alice opinion, and of most of the other Supreme Court subject matter opinions $^{117}$, one might expect the framework's 'inventive concept' requirement to raise

115 See Burk, supra note 100 at 587, 588 (2006).

116 See supra notes 10 and 83.

117 See eg Bilski v. Kappos, 561 U.S. 593 (2010) (computer-implemented process); Diamond v. Diehr (computer-implemented process); Parker v. Flook, 437 U.S. 584 (1978) (computer-implemented process); Gottshalk v. Benson, 409 U.S. 63 (1972) (computer-implemented process). 
similarly intractable issues in the context of data processing. ${ }^{118}$ This makes clear that, far from settling ongoing questions about patentable subject matter, the Supreme Court's Alice opinion leaves unsettled questions that will haunt us for years to come.

\section{ACKNOWLEDGEMENTS}

My thanks to Alain Pottage for prompting this research, and to two anonymous reviewers for helpful comments on a previous version of the paper. I have no financial, personal, academic, or other conflicts of interest in the subject matter discussed in this manuscript.

118 For example, an ongoing question in software patenting remains the extent to which the configuration of standard hardware by novel software defines a new machine. See Andrew Chin, Ghost in the 'New Machine': How Alice Exposed Software Patenting's Category Mistake, 16 N.C.J.L. \& TeCH. 623 (2015). 